\title{
ESTIMASI KETIDAKPASTIAN ANALISIS RADIONUKLIDA Ra-226, Ra-228, Th-228 DAN K-40 DALAM CUPLIKAN SEDIMEN DENGAN TEKNIK SPEKTROMETRI GAMMA
}

\author{
Sukirno, Samin \\ Pusat Teknologi Akselerator dan Proses Bahan BATAN Yogyakarta \\ Jl Babarsari Kotak Pos 6101 ykbb, Yogyakarta 55281
}

Diterima 30 Agustus 2010, diterima dalam bentuk perbaikan 22 Oktober 2010, disetujui 26 Oktober 2010

\begin{abstract}
ABSTRAK
ESTIMASI KETIDAKPASTIAN ANALISIS RADIONUKLIDA Ra-226, Ra-228, Th-228 DAN K-40 DALAM CUPLIKAN SIDIMEN DENGAN TEKNIK SPEKTROMETRI GAMMA. Nilai suatu hasil pengujian tidak akan bermakna tanpa disertai dengan perhitungan nilai ketidakpastian. Demikian juga pada hasil penentuan radionuklida Ra-226, Ra-228, Th-228 dan K-40 dalam cuplikan sedimen. Tujuan penelitian ini adalah menentukan nilai ketidakpastian pengukuran radionuklida Ra-226, Th-228, Ra-228 dan K-40 untuk memenuhi persyaratan ISO/IEC guide 17025-2005 yang telah diterapkan pada laboratorium kimia analitik Pusat Teknologi Akselerator dan Proses Bahan. Untuk itu telah dilakukan penaksiran nilai ketidakpastian perhitungan pada analisis Ra-226, Ra-228, Th-228 dan K-40 yang terkandung dalam sedimen. Cuplikan sedimen halus ditimbang $100 \mathrm{~g}$ dan dicacah dengan spektrometri gamma. Analisis secara kuantitatif dilakukan dengan metoda absolut dan komparatif dengan bahan standar pembanding Reference Material IAEA-315. Berdasarkan perhitungan gabungan pada cakupan 2 dengan tingkat kepercayaan $95 \%$ diperoleh ketidakpastian masing masing radionuklida untuk metoda absolut Ra-226 $= \pm$ 1,3 dari konsentrasi 19,01 Bq/kg, Th-228 = \pm 4,1 dari konsentrasi 76,28 Bq/kg, Ra-228 = \pm 2,1 dari konsentrasi $54,61 \mathrm{~Bq} / \mathrm{kg}$, dan $\mathrm{K}-40= \pm 11,8$ dari konsentrasi 206,81 Bq/kg, akan memberikan hasil analisis yang tepat dengan relatif deviasi di bawah $9 \%$ dan rentang ketidakpastian relatif lebih kecil dari $10 \%$
\end{abstract}

Kata kunci : Ketidakpastian, spektrometer gamma, Radionuklida Ra-226, Ra-228, Th-228, K-40

\begin{abstract}
THE ESTIMATION OF UNCERTAINTY OF ANALYSIS OF Ra-226, Ra-228, Th-228 AND K-40 IN SEDIMENT SAMPLE BY GAMMA SPECTROMETRY METHOD. The result value of testing is meaningless if it isn't completed with uncertainty value. So that with the determination result Ra-226, Ra-228, Th-228 and K-40 in the sediment sample. It was assessed the uncertainty measurement of Ra-226, Ra-228, Th-228 and K-40 analysis in sediment. The aim of the research is to determinations the uncertainty measurement of Ra-226, Ra-228, Th-228 and K-40, to fulfill the terms of ISO/IEC guide 17025-2005, wich applied at laboratory of analytical chemistry, Centre for Accelerator and Material Process Technology. It was assessed the uncertainty measurement of Ra-226, Ra-228, Th-228 and K-40 analysis in sediment. Sediment samples were weighted for $100 \mathrm{~g}$ and counted with gamma spectrometry. Quantitative analyzed using absolute and comparative method with Standard Reference Material IAEA-315. Based on calculated at confidence level $95 \%$ were obtained Ra-226 $= \pm 1,3$ from concentration of 19,01 $\mathrm{Bq} / \mathrm{kg}$, Th-228 $= \pm 4,1$ from concentration of 77,81 Bq/kg, Ra-228 $= \pm 2.1$ from concentration of 54,61 Bq/kg, and $K-40= \pm 11.8$ from concentrasi of $206,81 \mathrm{~Bq} / \mathrm{kg}$, will give result of correct analysis relative deviation below $9 \%$ and span uncertainty relative than $10 \%$.
\end{abstract}

Keyword: Uncertainty, sediment, gamma spectometer, Radionuclide of Ra-226, Ra-228, Th-228, K-40

\section{PENDAHULUAN}

pektrometer gamma merupakan salah satu komponen yang sangat mempengaruhi keandalan hasil kegiatan analisis radioaktivitas pemancar gamma seperti radionuklida alam dalam cuplikan lingkungan padatan maupun cairan. Spektrometer gamma sering juga digunakan untuk menganalisis naturally occurring radioactive materials (NORM) merupakan produk samping dalam proses kegiatan berupa industri yang perlu dipantau dan dikelola sedemikian rupa mengingat material ini adalah bahan radioaktif. NORM sering mengakumulasi pada konsentrasi yang meningkat dalam limbah hasil samping. Radionuklida utama yang menonjol dalam limbah NORM adalah radium-226 $\left({ }^{226} \mathrm{Ra}\right)$, dalam deret peluruhan uranium-238 $\left({ }^{238} \mathrm{U}\right)$, dan radium-228 $\left({ }^{228} \mathrm{Ra}\right)$, dalam deret peluruhan torium-232 (232Th). Limbah produksi yang kemungkinan besar terkontaminasi oleh konsentrasi 
radium yang meningkat meliputi air, scale, dan sludge ${ }^{(1)}$. Yang tidak kalah pentingnya spektrometer gamma untuk unjuk kerja pada analisis aktivasi neutron (AAN), merupakan metoda analisis yang memeliki selektivitas, sensitivitas dan keakuratan tinggi sampai skala nanogram ${ }^{(2,3)}$.

Pusat Teknologi Akselerator dan Proses Bahan (PTAPB) mempunyai alat spektrometer gamma 2 buah, yaitu spektrometer y Ortec dengan detektor $\mathrm{Ge}(\mathrm{Li})$ dengan perangkat lunak maestro II EG\&G dan spektrometer y Canberra dengan detektor HPGe dengan perangkat lunak Genie-2000 Canberra. Untuk menganalisis radionuklida biasanya dipakai spektrometer y Ortec, sedangkan spektrometer y Canberra digunakan untuk kegunaan AAN dan AAN-Ko. Alat spektrometri gamma ini selain digunakan untuk penelitian analisis logam berat dari lingkungan kimia analitik maupun dari lingkungan kimia proses dan untuk mendukung pendapatan negara bukan pajak (PNBP).

Untuk mendukung penelitian menggunakan spektometer gamma tersebut diperlukan suatu pengakuan tentang kebenaran penelitian hasil uji pada alat tersebut. Salah satu hasil uji yang diperlukan dalam rangka memperoleh perluasan akreditasi adalah ketidakpastian pengukuran, sehingga diperoleh pengakuan dari penggunaan yang dituangkan dalam sertifikat mutu dari Komite Akreditasi Nasional (KAN).

Ketidakpastian adalah suatu parameter yang menetapkan rentang nilai yang di dalamnya diperkirakan nilai benar yang diukur itu berada. Menghitung rentang tersebut dikenal sebagai pengukuran ketidakpastian. Ketidakpastian pengukuran memadukan semua kesalahan yang diketahui menjadi suatu rentang tunggal ${ }^{(2,4)}$. Rentang tersebut terpusat pada nilai hasil pengukuran dan menggambarkan sebaran hasil pengukuram.

Tujuan penelitian ini adalah menentukan nilai ketidakpastian pengukuran radionuklida Ra-226, Th-228, Ra-228 dan K-40 untuk memenuhi persyaratan ISO/IEC guide 17025-2005 yang telah diterapkan pada laboratorium kimia analitik Pusat Teknologi Akselerator dan Proses Bahan.

\section{TEORI}

Perhitungan ketidakpastian dilakukan dengan menyusun suatu model dari sistem pengukuran untuk mengetahui semua faktor yang dapat memberikan konstribusi kesalahan terhadap hasil akhir pengukuran. Faktor-faktor tersebut dievaluasi dan dikualintifikasi berdasarkan kategori sumber kesalahan, yaitu secara statistik untuk tipe $A$ yang dievaluasi dari analisis rangkaian pengamatan dan untuk tipe $B$ yang dievaluasi dengan cara selain dari analisis serangkaian pengamatan, berdasarkan informasi dari katalog, spesifikasi dari pabrik dan sebagainya berdasarkan informasi yang dapat dipercaya ${ }^{(2,5,6)}$. Kuantifikasi kesalahan tersebut dilakukan untuk mendapatkan ketidakpastian baku dari setiap komponen. Selanjutnya ketidakpastian baku digabungkan untuk mendapatkan ketidakpastian baku gabungan

\section{Evaluasi ketidakpastian baku tipe $\mathrm{A}$}

Apabila suatu pengukuran diulangi $n$ kali, maka nilai rerata dan simpangan bakunya dapat dihitung. Simpangan baku (S) adalah suatu taksiran sebaran populasi dimana $\mathrm{n}$ nilai tersebut diambil, yaitu:

$$
S=\left[\Sigma\left(X_{i}-X\right)^{2}\right]^{0,5} / n-1
$$

Perhitungan ketidakpastian baku tipe $A(\mu)$, perkiraan ketidakpastiannya dengan cara pengukuran atau pengamatan berulang, maka dapat dihitung kembali nilai rata-ratanya.

$$
\mu=S / \sqrt{ } n
$$

\section{Evaluasi ketidakpastian baku tipe $B$}

Perhitungan ketidakpastian baku tipe $B(\mu)$, nilai ketidakpastian yang dilaporkan bersumber dari acuan dalam sertifikat, dibagi dengan faktor cakupan yang diberikan dalam acuan sertifikat, bila tidak ada informasi faktor cakupan, maka dapat diambil 2 (dua) untuk distribusi normal persamaan (3) dan distribusi rektangular persamaan (4) dengan tingkat kepercayaan $95 \%$

$$
\begin{aligned}
& \mu(x)=S / 2, \text { atau } S / 1,96 \\
& \mu(x)=S / \sqrt{ } 3
\end{aligned}
$$


Perhitungan ketidakpastian gabungan $\left(\mu_{\mathrm{c}}\right)$ semua ketidakpastian baku atau persamaan umum untuk menggabungkan nilai ketidakpastian baku dari komponen-komponennya menjadi ketidakpastian baku gabungan yaitu dijumlahkan, dikuadratkan dan ditarik akar pangkat dua dari jumlahnya. Untuk penjumlahan atau pengurangan, misal $Y=A+B$, maka perhitungan ketidakpastian gabungan $\left(\mu_{\mathrm{c}}\right)$.

$$
\mu_{c}{ }^{2}=\mu_{B}{ }^{2}+\mu_{c}^{2} \text { atau } \mu_{c}=\left(\mu_{B}{ }^{2}+\mu_{c}{ }^{2}\right)^{0,5}
$$

Ketidakpastian diperluas (U), untuk mendapatkan probabilitas yang memadai bahwa nilai hasil uji berada dalam rentang yang diberikan oleh ketidakpastian, maka ketidakpastian baku gabungan dikalikan dengan sebuah faktor pencakupan ( $k$ ). Tingkat kepercayaan sekitar $95 \%$ memberikan faktor pencakupan $2(k=2)$ untuk ketidakpastian diperluas.

$$
U=k \cdot \mu_{c}
$$

\section{METODOLOGI}

\section{Alat}

Seperangkat spektrometer gamma dengan menggunakan detektor $\mathrm{Ge}(\mathrm{Li})$, timbangan analitik yang terkalibrasi, alat penjemur cuplikan dan wadah pencacahan.

\section{Bahan}

Standard reference material (SRM) IAEA-315 Radionuclides in marine sediment, sedimen laut, standar kalibrasi alat yaitu radionuklida Eu-152

\section{Preparasi contoh uji}

Cuplikan sedimen Lemahabang semenanjung Muria, sedimen dibersihkan dari kotoran dan dikeringkan kemudian digerus sampai halus lolos 100 mesh dan dihomogenkan dan dimasukkan ketempat yang berlabel. Cuplikan/contoh uji sedimen dan standar SRM ditimbang seberat 4 gram dalam wadah pencacahan.

\section{Penimbangan cuplikan}

Timbangan elektronik semi-mikro tipe/ Model GT 410 buatan OHOUS Corp USA, Nomor Serifikat: S.060-0018/VII//LS/05 dengan kapasitas maksimal $410 \mathrm{~g}$ dan resolusi $1,0 \mathrm{mg}$, ketidakpastian timbangan tersebut adalah $\mu= \pm 1,401 \mathrm{mg}$, ripitabilitas penimbangan dilakukan 10 kali ulang didapatkan standar deviasi ripitabilitas $0,8 \mathrm{mg}^{(7)}$. Sampel sedimen laut Lemahabang dan cuplikan standar SRM masing-masing ditimbang 100 gram $(0,1 \mathrm{~kg})$ dalam vial pencacahan.

\section{Pencacahan dan penentuan konsentrasi radionuklida}

Pencacahan dilakukan selama 28800 detik untuk contoh uji sedimen dan standar SRM. Untuk pencacahan radionuklida Ra-226, Th-228, Ra-228 dan K-40. Dalam penelitian ini untuk menghitung konsentrasi (aktivitas) cuplikan digunakan metoda absolute dan komparatif, oleh karena itu cuplikan standar yang mengandung radionuklida yang akan ditentukan, yang jumlah dan komposissi aktivitasnya telah diketahui dengan pasti.

Rumus penentuan konsentrasi radionuklida dalan cuplikan contoh uji:

Metoda absolute :

$$
\text { Konsentrasi }(\mathrm{Cc})=\frac{\mathrm{cps}}{\varepsilon \cdot \mathrm{P}_{\mathrm{y}}}
$$

Metoda komparatif :

$$
\text { Konsentrasi }(C c)=\frac{I_{c}}{I_{s}} \cdot C_{s}
$$

cps $=$ cacah per sekan $\quad \varepsilon=$ efisiensi detektor,

Cs $=$ konsentrasi radionuklida dalam standar (SRM)

$$
\text { Py }=\text { Probabilitas radionuklida }
$$

Ic dan Is = cps radionuklida yang diperhatikan dalam contoh uji dan standar 
Estimasi Ketidakpastian Analisis Radionuklida Ra-226, Ra-228, Th-228 dan K-40 dalam Cuplikan Sedimen dengan Teknik Spektrotrimetri Gamma (Sukirno, Samin)

\section{Pengaruh ketidakpastian timbangan}

Nilai ketidakpastian pada timbangan akan dipengaruhi oleh kalibrasi timbangan, kemampuan pembacaan skala (resolusi) dan repitabilitas. Perhitungan ketidakpastian gabungan penimbangan $\left(\mu_{\mathrm{c}}\right)$ untuk sampel dan standar, dijumlahkan, dikuadratkan dan ditarik akar pangkat dua dari jumlah.

\section{Pengaruh ketidakpastian penimbangan dan pencacahan sampel dan standar}

Nilai ketidakpastian baku penimbangan dan statistik pencacahan akan dipengaruhi pada penimbangan sampel dan standar serta nilai ketidakpastian yang tertera pada acuan standar SRM, juga dipengaruhi oleh statistik pencacahan dan simpangan baku atau standar deviasi dari sampel dan standar yang dipergunakan. Dari ketidakpastian individu masing-masing kemudian dilakukan perhitungan ketidakpastian gabungan dan ketidakpastian diperluas. Untuk menentukan perhitungan ketidakpastian dari radionuklida yang diperhatikan yaitu Ra-226, Th-228, Ra-228 dan K-40, dari ke 4 radionuklida ini diambil radionuklida Ra-226 sebagai contoh perhitungan dalam pembahasan.

\section{HASIL DAN PEMBAHASAN}

\section{Hasil perhitungan radionuklida dalam cuplikan sedimen}

Pada penentuan spektrum spektrometri gamma dari analisis sedimen cuplikan contoh uji sedimen, diidentifikasi pada puncak-puncak gamma karakteristik ${ }^{(8,9)}$ dan pada umumnya radionuklida mempunyai lebih daripada satu tenaga karakteristik, sehingga dipilih yang mempunyai probabilitas yang terbesar. Pada penelitian ini dipilih energi karakteristik radionuklida Ra-266 (186,0 keV), Th-228 (238,6 keV), Ra-228 (911 keV) dan K-40 (KeV).

Hasil hitung $\mathrm{cps} / \mathrm{kg}$ dan $\mathrm{dps} / \mathrm{kg}(\mathrm{Bg} / \mathrm{kg})$ untuk cuplikan sedimen Lemahabang semenanjung Muria (hasil rerata) dan standar deviasi (SD), disajikan pada Tabel 1, dengan pengulangan cacah 7 kali. Dari perhitungan dengan metoda absolut untuk menentukan konsentrasi (aktivitas) menggunakan persamaan (7). Pada Tabel 1 tersaji konsentrasi Ra-266 = 19,01 Bq/kg, Th-228 = 76,27 Bq/kg, Ra-228 54,62 Bq/kg dan K-40 = 206,82 Bq $/ \mathrm{kg}$. Radionuklida K-40 merupakan konsentrasi yang tertinggi dari keempat radionuklida dan yang mempunyai konsentrasi terendah adalah Ra-226. Nilai cps rerata dan standar deviasi (SD) dipergunakan untuk perhitungan ketidakpastiannya.

Tabel 1. Hasil hitung cps $/ \mathrm{kg}$ dan $\mathrm{dps} / \mathrm{kg}(\mathrm{Bq} / \mathrm{kg})$ untuk cuplikan sedimen Lemahabang semenanjung Muria (hasil rerata) dan standar deviasi (SD)

\begin{tabular}{|c|c|c|c|c|c|c|c|c|}
\hline \multirow{3}{*}{ Nomor } & \multicolumn{8}{|c|}{ Aktivitas Radionuklida } \\
\hline & \multicolumn{4}{|c|}{$\mathrm{cps} / \mathrm{kg}$} & \multicolumn{4}{|c|}{$\mathrm{dps} / \mathrm{kg}$} \\
\hline & Ra-226 & Th-288 & Ra-288 & $\mathrm{K}-40$ & Ra-226 & Th-288 & Ra-288 & K-40 \\
\hline$\overline{11}$ & 0,0291 & 1,1235 & 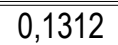 & 0,1137 & 177,689 & 75,244 & 56,392 & 221,781 \\
\hline 2 & 0,0335 & 1,0725 & 0,1239 & 0,0984 & 20,342 & 71,828 & 53,259 & 191,926 \\
\hline 3 & 0,0328 & 1,1324 & 0,1282 & 0,1042 & 19,949 & 75,835 & 55,138 & 202,24 \\
\hline 4 & 0,0305 & 1,1300 & 0,1213 & 0,1019 & 18,544 & 75,680 & 52,153 & 198,724 \\
\hline 5 & 0,0296 & 1,1578 & 0,1271 & 0,1186 & 17,990 & 77,540 & 54,666 & 231,345 \\
\hline 6 & 0,0311 & 1,1607 & 0,1293 & 0,1061 & 18,857 & 77,731 & 55,588 & 206,957 \\
\hline 7 & 0,0325 & 1,1950 & 0,1282 & 0,0993 & 19,724 & 80,027 & 55,127 & 193,717 \\
\hline Rerata & 0,0313 & 1,1388 & 0,1270 & 0,106 & 19,014 & 76,270 & 54,618 & 206,823 \\
\hline $\mathrm{SD}( \pm)$ & 0,0014 & 0,0277 & 0,0025 & 0,0058 & 0,8498 & 1,8541 & 1,0924 & 11,327 \\
\hline
\end{tabular}

\section{Faktor-faktor yang berpengaruh pada ketidakpastian metoda}

Faktor-faktor yang mempengaruhi untuk menentukan ketidakpastian dalam cuplikan uji sedimen laut dari semenanjung Muria, terdapat beberapa langkah yang harus diperhatikan, dari tahapan preparasi sampel, probabilitas radionuklida, efisiensi detektor, kemurnian standar dan pencacahan. Selanjutnya penyusunan suatu model dari langkah pekerjaan dan melakukan estimasi masing-masing komponen ketidakpastian, sehingga ekivalen dengan simpangan baku, serta menggabungkan komponen ketidakpastian baku untuk menghasikan ketidakpastian baku gabungan. Nilai ketidakpastian yang diperoleh diperluas untuk memberikan suatu interval dimana kualitas yang diukur diperkirakan berada dan pada tingkatan kepercayaan tertentu. 
Faktor-faktor yang berpengaruh pada ketidakpastian terlihat pada Gambar 1 merupakan metoda absolut dan Gambar 2 merupakan metoda komparatif.

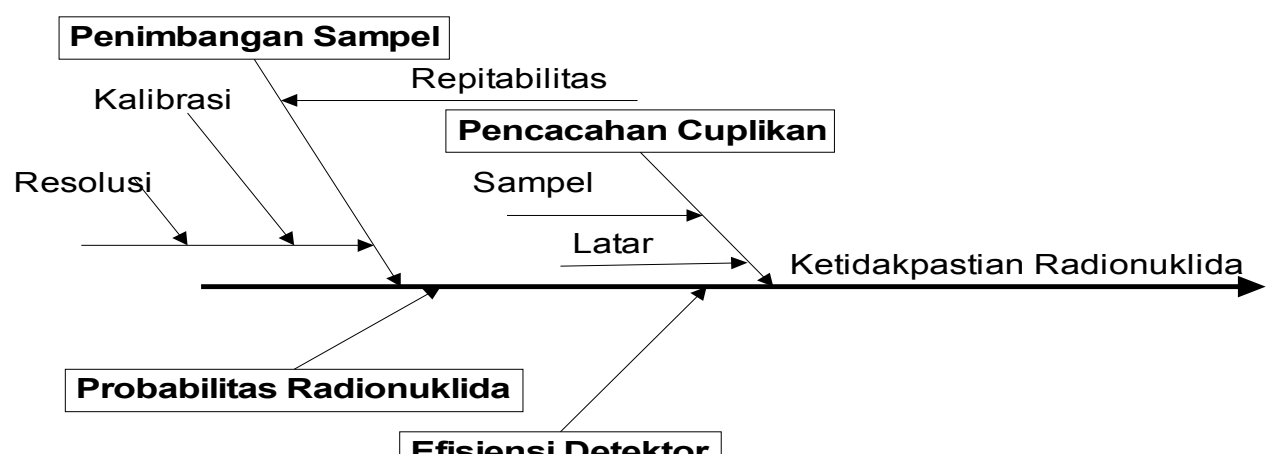

Gambar 1. Cause and effect diagram (fish bone) pada penentuan ketidakpastian dengan metoda absolut.

\section{Perhitungan ketidakpastian untuk radionuklida Ra-226 dalam contoh uji sedimen dengan metoda absolut.}

Perhitungan ketidakpastian menentukan konsentrasi untuk radionuklida Ra-226 dalam contoh uji sedimen dengan metoda komparatif dan absolut menggunakan standar pembanding SRM, disajikan pada Tabel $2-8 \mathrm{di}$ bawah ini. Preparasi sampel dan standar, sumber ketidakpastian diantaranya berasal dari penimbangan dan kemurnian standar. Komponen ketidakpastian dari penimbangan mengambil contoh untuk radionuklida Ra-226 dalam sampel sedimen.

Komponen ketidakpastian dari timbangan yang digunakan adalah timbangan elektronik tipe/ Model Gt 410 buatan OHOUS Corp USA, Nomor Serifikat: S.060-0018/VII/LS/05 dengan kapasitas maksimal $410 \mathrm{~g}$ dan resolusi $1,0 \mathrm{mg}$. Pada sertifikat kalibrasi timbangan yang digunakan tertera ketidakpastian timbangan tersebut adalah $\mu= \pm 1,401 \mathrm{mg}^{(7)}$. Dengan faktor cakupan adalah 2 , maka ketidakpastian baku $\left(\mu_{\mathrm{bt}}\right)$ adalah 1,401/2 = $0,7005 \mathrm{mg}$. Resolusi timbangan menggunakan 3 digit maka pada pembacaan timbangan adalah 1,0 mg, maka ketidakpastian baku $\left(\mu_{\text {br }}\right)$ menggunakan persamaan (3) dan faktor cakupan 2 (ketidakpastian tipe B) adalah 1/2/ $\sqrt{3}=0,28867 \mathrm{mg}$. Repitabilitas penimbangan dilakukan 10 kali pengulangan didapatkan standar deviasi ripitabilitas $0,8 \mathrm{mg}$, maka ketidakpastian baku $\left(\mu_{\mathrm{bR}}\right)$ menggunakan persamaan (1) (ketidakpastian tipe A) adalah $0,8 / \sqrt{ } 10=0,2529 \mathrm{mg}$. Ketidakpastian gabungan dari penimbangan cuplikan yang terdiri dari ketiga komponen yang telah dihitung di atas adalah $0,79877 \mathrm{mg}$.

Tabel.2. Ketidakpastian pada pengaruh penimbangan dalam sampel sedimen

\begin{tabular}{|l|c|c|c|}
\hline \multicolumn{1}{|c|}{ Kuantitas } & Ketidakpastian & $\boldsymbol{\mu}(\mathbf{m g})$ & Tipe \\
\hline \hline Kalibrasi timbangan & $1,401 \mathrm{mg}$ & $1,401 / 2=0,7005$ & $\mathrm{~B}$ \\
\hline Resolusi & $0,001 \mathrm{~g}=1 \mathrm{mg}$ & $1 / 2 / \sqrt{3}=0,28867$ & $\mathrm{~B}$ \\
\hline Ripitabilitas $(\mathrm{n}=10)$ & $0,0008 \mathrm{~g}=0,8 \mathrm{mg}$ & $0,8 / \sqrt{10}=0,25298$ & $\mathrm{~A}$ \\
\hline $\begin{array}{l}\text { Pengaruh ketidakpastian penimbangan } \\
\text { terhadap pencacahan }\end{array}$ & $\begin{array}{l}{\left[(0,7005)^{2}+(0,28867)^{2}+(0,25298)^{2}\right]^{0,5}} \\
=0.79877\end{array}$ & \\
\hline
\end{tabular}

Selanjutnya ketidakpastian gabungan faktor-faktor tersebut hanya terbatas pada statistik pencacahan, dengan menggunakan metoda komparatif dan absolut. Dari Tabel 1 hasil analisis pengukuran $\mathrm{cps} / \mathrm{kg}$ (cacah per sekan per kg) untuk radionuklida Ra-226 dengan statistik pencacahan sebesar 0,0313 cps/kg dan mempunyai nilai standar deviasi $(\mathrm{SD})=0,0014 \mathrm{cps} / \mathrm{kg}$ dengan pengulangan pencacahan $7 \mathrm{kali}$.

Ketidakpastian baku dan gabungan contoh uji sampel radionuklida Ra-226 dapat dilihat pada Tabel 3. Untuk memudahkan menyederhanakan keseragaman yang lebih jelas satuan ketidakpastian dibuat dalam prosentase (\%). Ketidakpastian preparasi sampel dan standar masing-masing berat $100 \mathrm{~g}$ dan $70 \mathrm{~g}$, menghasilkan ketidakpastian baku sampel dengan nilai 0,000799 \% dan ketidakpastian baku standar dengan nilai $0,001141 \%$ (Tabel 4). 
Statistik hasil pencacahan contoh uji sedimen menghasilkan ketidakpastian baku masing-masing sebesar $3,319608 \%$. Koreksi yang berasal dari konstanta nuklir (probabilitas radinuklida Ra-226 $=3,6 \%{ }^{(8)}$ ) diambil $5 \%$ dengan asumsi distribusi data normal, maka ketidakpastian probabilitas radionuklida Ra-226 $\left(\mu_{p}\right)$ baku adalah $(5$ $\% \times 0,036) / 2=0,09 \%$ dan ketidak pastian efisiensi detektor sebesar $11 \%$. Dari nilai yang ada dapat ditentukan ketidakpastian gabungan pada penimbangan cuplikan contoh uji (I) yaitu sebesar 3,3227 \% dapat dilihat pada Tabel 3.

Tabel 3. Ketidakpastian baku pada analisis Ra-226 dalam sampel

\begin{tabular}{|l|c|}
\hline Kuantitas & Ketidakpastian baku \\
\hline \hline Preparasi sampel $100.000 \mathrm{mg}=0,79877 / 100.000^{*} 100 \%=0,00079877 \%$ & $0,000799 \%$ \\
\hline $\begin{array}{l}\text { Statistik pencahan sampel } 0,031329 \text { dan standar deviasi }=0,00104 \\
=\mu(\%) \text { sampel }=(0,00104 / 0,031329)^{*} 100 \%=3,319608 \%\end{array}$ & $3,319608 \%$ \\
\hline$\mu_{\mathrm{p}}$ probabilitas Ra-2266 $=0,036=5 \% * 036 / 2=0,0009=0,09 \%$ & $0,09 \%$ \\
\hline Ketidakpastian baku detektor Ra-266 $=0.0022=0,0022 / 2^{*} 100 \%=0,11 \%$ & $0,11 \%$ \\
\hline $\begin{array}{l}\text { Ketidakpastian gabungan sampel }(\mathrm{I})\left[(3,319608)^{2}+(0,0079877)^{2}+(0,09)^{2}+(0,11)^{2}\right]^{0,5}= \\
3,3227\end{array}$ & $3,3227 \%$ \\
\hline
\end{tabular}

Dari ketidakpastian gabungan sampel $(I)$, dengan faktor cakupan $(k=2)$ maka ketidakpastian diperluas menjadi 6,6453 \%. Konsentrasi atau aktivitas radionuklida dapat ditentukan dengan persamaan (8), dapat juga dilihat hasil pada Tabel 1 dimana konsentrasi untuk radionuklida Ra-226 adalah 19,0135 Bq/kg. Pada Tabel 4 ketidakpastian diperluas 6,6453 \% sama dengan 1,2635 Bq/kg, sehingga konsentrasi radionuklida Ra-226 dengan metoda absolut dalam sedimen laut Lemahabang nilainya terletak diantara 19,01 $\pm 1,26 \mathrm{~Bq} / \mathrm{kg}$. Analog radionuklida Ra-266, untuk ketidakpastian dan konsentrasi Th-228, Ra-288 dan K-40 disajikan pada Tabel 8. Hasil hitung metoda absolut konsentrasi Th-288 adalah 76,28 Bg/kg dan ketidakpastiannya mempunyai nilai 4,1 $\mathrm{Bq} / \mathrm{kg}$, sehingga nilai konsentrasi menjadi $76,28 \pm 4,1 \mathrm{Bg} / \mathrm{kg}$, begitu juga untuk konsentrasi Ra-288 adalah 54,61 $\pm 2,1 \mathrm{~Bq} / \mathrm{kg}$ dan $\mathrm{K}-40$ adalah $=206,81 \pm 5,7 \mathrm{~Bq} / \mathrm{kg}$.

Tabel 4. Hasil perhitungan ketidakpastian dan aktivitas (konsentrasi) secara absolut

\begin{tabular}{|l|l|}
\hline Ketidakpastian gabungan $(\mathrm{I})$ & $3,3227 \%$ \\
\hline Ketidakpastian gabungan $(\mathrm{I})$ diperluas $=2{ }^{*} 3,3227=6,6453$ & $6,6453 \%$ \\
\hline Aktivitas Ra-226 (absolut) $=0,031329 /\left(0,0036^{*} 0,0458\right)=19,0135$ & 19,0135 \\
\hline Ketidakpastian diperluas $=(6.6452985 / 100)^{*} 19,0135=1,2635$ & 1,2635 \\
\hline Aktivitas (konsentrasi) Ra-226 menjadi $=19,0135 \pm 1,263$ & $19,01 \pm 1,26 \mathrm{~Bq} / \mathrm{kg}$ \\
\hline
\end{tabular}

Gambar 2 merupakan Cause and effect diagram (fish bone) pada penentuan ketidakpastian dengan metoda komparatif. Identifikasi dan analisis sumber-sumber ketidakpastian, selain dipengaruhi seperti ketidakpastian metoda absolut, metoda komparatif akan berpengaruh terhadap kemurnian standar sebagai pembanding.

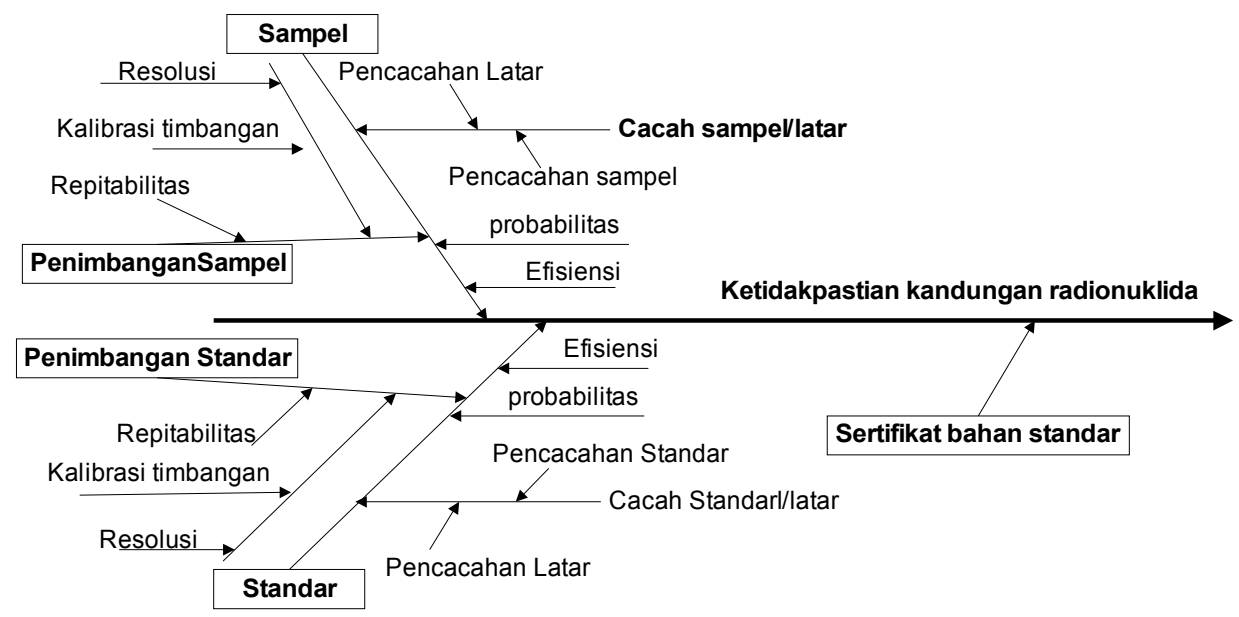

Gambar 2. Cause and effect diagram (fish bone) pada penentuan ketidakpastian dengan metoda komparatif. 


\section{Perhitungan ketidakpastian untuk radionuklida Ra-226 dalam contoh uji sedimen dengan metoda komparatif.}

Untuk menentukan ketidakpastian dan konsentrasi atau aktivitas radionuklida digunakan standard reference material (SRM) IAEA-315 Radionuclides in marine sediment dan untuk perhitungan diambil contoh radionuklida Ra-226. Konsentrasi radionuklida $\mathrm{Ra}-226$ dalam sertifikat adalah $13,8 \pm 0,7 \mathrm{~Bq} / \mathrm{kg}^{(10)}$ yang merupakan standar primer yang digunakan sebagai pembanding. Pada Tabel 5 merupakan hasil rerata hitung $\mathrm{cps} / \mathrm{kg}$ untuk standar sedimen dan standar diviasi (SD), misal radionuklida Ra-226 mempunyai aktivitas 0,02011 $\mathrm{cps} / \mathrm{kg}$ dengan nilai standar diviasi sebesar 0,00136 cps $/ \mathrm{kg}$.

Untuk menentukan ketidakpastian baku metoda komparatif hampir sama dengan metoda absolut, yang membedakan adalah pada metoda ini menggunakan standar sebagai pembanding dan kemurnian standar akan mempengaruhi dari pada hasil ketidakpastian maupun hasil konsentrasi radionuklida dalam sedimen. Penentuan ketidakpastian gabungan standar (II), berasal dari ketidakpastian baku penimbangan sampel, statistik pencacahan dari Tabel 5, penggunakan SRM yang telah diketahui kemurniannya dalam sertifikat, probabilitas radionuklida dan efisiensi detektor. Perhitungan ketidakpastian gabungan (II) ini dijumlahkan dikuadratkan dan ditarik akar pangkat dua dari jumlah, hasilnya dapat dilihat pada Tabel 6 yaitu 5,245508\%.

Tabel 5. Hasil rerata hitung $\mathrm{cps} / \mathrm{kg}$ untuk standar sedimen dan standar diviasi (SD)

\begin{tabular}{|c|c|c|c|c|c|c|c|c|}
\hline Nomor & \multicolumn{2}{|c|}{ Ra-226 } & \multicolumn{2}{c|}{ Th-228 } & \multicolumn{2}{c|}{ Ra-228 } & \multicolumn{2}{|c|}{ K-40 } \\
\hline $1-2$ & 0,02143 & 0,02050 & 0,4000 & 0,3942 & 0,0614 & 0,0582 & 0,1429 & 0,1422 \\
\hline $3-4$ & 0,02183 & 0,02431 & 0,3810 & 0,3676 & 0,0585 & 0,0615 & 0,1448 & 0,1374 \\
\hline $5-6$ & 0,02381 & 0,02212 & 0,4034 & 0,3687 & 0,0589 & 0,0599 & 0,1422 & 0,135 \\
\hline $7-8$ & 0,02143 & 0,02381 & 0,3871 & 0,4345 & 0,0614 & 0,0542 & 0,1514 & 0,1488 \\
\hline $9-10$ & 0,02183 & 0,02551 & 0,3899 & 0,4255 & 0,0615 & 0,0630 & 0,1498 & 0,1543 \\
\hline Rerata & \multicolumn{2}{|c|}{0,02011} & \multicolumn{2}{c|}{0,3526} & \multicolumn{2}{c|}{0,0536} & 0,1295 \\
\hline SD & \multicolumn{2}{|c|}{0,00136} & \multicolumn{2}{c|}{0,0165} & \multicolumn{2}{c|}{0,0019} & \multicolumn{2}{c|}{0,005} \\
\hline
\end{tabular}

Tabel 6. Ketidakpastian baku pada analisis Ra-226 dalam standar

\begin{tabular}{|l|c|}
\hline Kuantitas & Ketidakpastian baku \\
\hline \hline Preparasi standar $70 \mathrm{mg}=0,79845 / 70.000^{*} 100 \%=0,001141 \%$ & $0,001141 \%$ \\
\hline $\begin{array}{l}\text { Standar SRM }=13,8 \mathrm{Bg} / \mathrm{kg} \text { dan ketidakpastian }=0,7 \text { (tipe B) } \\
=(0,7 / 13,8)^{*} 100 \%=\left[(0,7 / 13,8)^{*} 100 \%\right] / 2=2,53623 \%\end{array}$ & $2,53623 \%$ \\
\hline $\begin{array}{l}\text { Statistik pencahan standar } 0,022657 \text { dan standar deviasi }=0,001362 \\
=\mu(\%) \text { standar }=(0,0013662 / 0,022657)^{*} 100 \%=6,011387 \%\end{array}$ & $6,011387 \%$ \\
\hline$\mu_{\mathrm{p}}$ probabilitas Ra-2266 $=0,036=5 \%{ }^{*} 0,036 / 2=0,0009=0.09 \%$ & $0,09 \%$ \\
\hline Ketidakpastian baku detektor Ra-266 $=0,0022=0,0022 / 2^{*} 100 \%=0,11 \%$ & $0,11 \%$ \\
\hline $\begin{array}{l}\text { Ketidakpastian gabungan standar }(\mathrm{II}) \\
{\left[(5,24358217)^{2}+(0,0011411)^{2}+(0,9)^{2}+(0,11)^{2}\right] 0,5=5,245508}\end{array}$ & $5,245508 \%$ \\
\hline
\end{tabular}

Penentuan ketidakpastian metoda komparatif akan melibatkan standar dan sampel yang akan diuji, sehingga dilakukan ketidakpastian gabungan (I), (II) dan ketidakpastian standar buku dalam hal ini SRM. Hasil perhitungan ketidakpastian gabungan ini menghasilkan nilai 4,8893 \%, dapat dilihat pada Tabel 7. Untuk menentukan konsentrasi pada metoda komparatif digunakan persamaan (8). Aktivitas Ra-226 dalam sampel 0,031329 cps pada hasil hitung di Tabel 1 dan aktivitas Ra-226 dalam standar 0,0225037 cps pada hasil hitung di Tabel 5 dan konsentrasi dalam sertifikat adalah $13,8 \mathrm{~Bq} / \mathrm{kg}$ akan menghasikan nilai konsentrasi sebesar $19,2119 \mathrm{~Bq} / \mathrm{kg}$. Ketidakpastian diperluas metoda komparatif menghasilkan nilai 9,7785 \% atau 1,878 Bq/kg. Maka nilai radionuklida Ra-226 dalam sedimen laut Lemahabang mempunyai nilai terletak diantara 19,21 $\pm 1,88$ $\mathrm{Bq} / \mathrm{kg}$ 
Estimasi Ketidakpastian Analisis Radionuklida Ra-226, Ra-228, Th-228 dan K-40 dalam Cuplikan Sedimen dengan Teknik Spektrotrimetri Gamma (Sukirno, Samin)

Tabel 7. Hasil perhitungan ketidakpastian dan aktivitas (konsentrasi) secara komparatif

\begin{tabular}{|l|l|}
\hline $\begin{array}{l}\text { Ketidakpastian gabungan }(\mathrm{I}) \text { dan }(\mathrm{II}) \\
{\left[(3.3227)^{2}+(5,245508)^{2}+(2,536232)^{2}\right]^{0.5}=4,8893}\end{array}$ & $4,8893 \%$ \\
\hline ketidakpastian $(\boldsymbol{\mu})$ diperluas $=2^{*} 4,88927=9,77853 \%$ & $9,77853 \%$ \\
\hline Aktivitas Ra-226 $=(0,031329 / 0,0225037)^{*} 13,8=19,21196$ & 19,2119 \\
\hline Ketidakpastian (komparatif) $=9,77853 \%{ }^{*} 19,2119=1,878$ & 1,778 \\
\hline Aktivitas (konsentrasi) Ra-226 menjadi $=19,2119 \pm 1,878$ & $19,21 \pm 1,88 \mathrm{~Bq} / \mathrm{kg}$ \\
\hline
\end{tabular}

Hasil perhitungan estimasi nilai ketidakpastian pada radionuklida Ra-226, Th-228, Ra-228 dan K-40 yang terkandung dalam sedimen disajikan pada Tabel 8. Perhitungan radionuklida Th-228, Ra-228 dan K-40, sama dengan contoh hitung konsentrasi dan ketidakpastian radionuklida Ra-266. Hasil hitung metoda komparatif konsentrasi Th-288 adalah $77,81 \mathrm{Bg} / \mathrm{kg}$ dan ketidakpastiannya mempunyai nilai $7,0 \mathrm{~Bq} / \mathrm{kg}$, sehingga nilai konsentrasi menjadi $77,81 \pm 7,0 \mathrm{Bg} / \mathrm{kg}$, begitu juga untuk konsentrasi Ra-288 adalah 56,65 \pm 4,5 Bq/kg dan $\mathrm{K}-40$ adalah $217,29 \pm 4,5 \mathrm{~Bq} / \mathrm{kg}$.

Hasil analisis radionuklida dalam sedimen laut Lemahang di semenanjung Muria dengan metoda komparatif maupun absolut, memberikan hasil analisis yang tepat dengan relatif deviasi yaitu perbandingan antara ketidakpastian radionuklida terhadap konsentrasi rerata radionuklidanya berkisar antara $(4,2-8,9) \%$ dan rentang ketidakpastian relatif lebih kecil dari $10 \%$. Nilai relatif deviasi juga menyatakan mutu hasil pengukuran atau pengujian, semakin kecil nilai relatif deviasi maka semakin baik hasil penelitian atau pengujian. Dengan melihat hasil estimasi ketidakpastian dan relatif deviasi hasil pengukuran tersebut, maka metoda teknik spektrometri gamma untuk menganalisis radionuklida Ra-226, Th-228, Ra-228 dan K-40 yang terkandung dalam contoh uji sedimen cukup andal, dapat dipertanggung jawabkan dan valid.

Tabel 8. Hasil perhitungan konsentrasi, ketidakpastian dan standar deviasi dalam sedimen

\begin{tabular}{|l|c|c|c|c|c|c|}
\hline \multirow{2}{*}{ Radionuklida } & \multicolumn{2}{|c|}{ Konsentrasi, Bq/kg } & \multicolumn{2}{c|}{ Ketidakpastian, Bq/kg } & \multicolumn{2}{c|}{ Standar deviasi, \% } \\
\cline { 2 - 7 } & Absolut & Komparatif & Absolut & komparatif & Absolut & Komparatif \\
\hline \hline Ra-226 & 19,01 & 19,21 & 1,3 & 1,7 & 6,6 & 8,5 \\
\hline Th-228 & 76,28 & 77,81 & 4,1 & 7,0 & 5,3 & 8,9 \\
\hline Ra-228 & 54,61 & 56,65 & 2,1 & 4,5 & 4,2 & 7,9 \\
\hline K-40 & 206,81 & 217,29 & 11,8 & 13,6 & 5,7 & 6,2 \\
\hline
\end{tabular}

\section{KESIMPULAN}

1. Ketidakpastian pengukuran memadukan semua kesalahan yang diketahui menjadi suatu rentang tunggal. Rentang tersebut terpusat pada nilai hasil pengukuran dan menggambarkan sebaran hasil pengukuran, dan komponen ketidakpastian berasal dari tahap operasi sampel maupun standar, kemurnian bahan, statistik pencacahan sampel, standar, serta ripitabilitas, efisiensi detektor dan probilitas radionuklida. Hasil estimasi ketidakpastian pengukuran pada analisis radionuklida Ra-226, Th-228, Ra-228 dan K-40 dilakukan dengan 2 (dua) metoda yaitu metoda absolut dan komparatif

2. Berdasarkan perhitungan gabungan pada cakupan 2 dengan tingkat kepercayaan $95 \%$ diperoleh ketidakpastian dan konsentrasi masing masing radionuklida untuk metoda absolut Ra-226 $= \pm 1,3$ dari konsentrasi 19,01 Bq/kg, Th-228 $= \pm 4,1$ dari konsentrasi 76,28 Bq/kg, Ra-228 $= \pm 2,1$ dari konsentrasi $54,61 \mathrm{Bg} / \mathrm{kg}$, dan K-40 $= \pm 11,8$ dari konsentrasi $206,81 \mathrm{~Bq} / \mathrm{kg}$. Untuk metoda komparatif nilai ketidakpastian Ra-226 $= \pm 1,7$ dari konsentrasi 19,21 Bq/kg, Th-228 $= \pm 7,0$ dari konsentrasi 77,81 Bq/kg, Ra-228 $= \pm 4,5$ dari konsentrasi $56,65 \mathrm{~Bq} / \mathrm{kg}$, dan K-40 $= \pm 13,6$ dari konsentrasi $217,29 \mathrm{~Bq} / \mathrm{kg}$.

3. Dari perhitungan kandungan radionuklida dala sedimen dan ketidakpastiannya untuk kedua metoda akan memberikan hasil analisis yang tepat dengan relatif deviasi di bawah $9 \%$ dan rentang ketidakpastian relatif lebih kecil dari $10 \%$

\section{DAFTAR PUSTAKA}

1. DJAROT.S WISNUBROTO. Pengolahan Limbah NORM/TENORM dari Kegiatan Industi No Nuklir. Prosiding Seminar Aspek Keselamatan Radiasi dan Lingkungan pada Industri No Nuklir. Jakarta (2003) 
2. YUSTINA TRI HANDAYANI., Ketidakpastian pada Analisis Aktivasi Neutron Dengan Metoda Ko. Pusdiklat BATAN, Jakarta (2006)

3. SUKIRNO. SUDARMADJI., "Pengukuran Radioaktivitas Gamma, Beta dan Identifikasi Radionuklida dalam Sedimen dan Air Sungai". Prosiding PPI_PDIPTN, P3TM-BATAN. Yogyakarta (2001)

4. SUKIRNO., AGUS TAFTAZANI. Penafsiran Nilai Ketidakpastian Analisis $\mathrm{Fe}, \mathrm{Ca}, \mathrm{Ze}, \mathrm{Ba}, \mathrm{La}$, Ti dan $\mathrm{Ce}$ dalam Cuplikan Sedimen Dengan Metoda XRF. Jurnal Iptek Nuklir GANENDRA. Vol 13 No 1 Januari 2010. PTAPB. BATAN Yogyakarta (2010)

5. ANWAR HADI. Pemahaman dan penerapan ISO/IEC 17025: 2005. Persyaratan umum kompentensi laboratorium pengujian dan laboratorium kalibrasi. PT Granmedia Pustaka Utama, Jakarta 2007

6. BSN., Persyaratan Umum Kompetensi Laboratorium Pengujian Kalibrasi, ISO/IEC 17025, edisi kedua, Jakarta (2005).

7. ANONIM., "SERTIFIKAT KALIBRASI" No Order : S.060-0018/VII/ILS/05, Timbangan Elektronik tipe GT 410. Laboratorium Kalibrasi Divisi Teknik, Indocal Laboratorium Sistem. Bandung (2005)

8. ERDTMANN.G., SOYKA.W., The Gamma rays of the Radionuclides, New York (1979)

9. IAEA. Meassurement of Radionuclides in Food and the Environment. A Guide Book., Technical Report Series No 295. Vienna (1989)

10. ANONIM., Standard Reference Material (SRM) IAEA-315 Radionuclides in Marine sediment, Vienna, (2000) 